\title{
Discursive media strategies in the journalistic construction of schistosomiasis in Jaboticatubas, Minas Gerais
}

\section{Celina Maria Modena, Cristiano Lara Massara*, Virginia Torres Schall/ ${ }^{+}$}

\author{
Laboratório de Educação em Saúde *Laboratório de Helmintoses Intestinais, Centro de Pesquisa René-Rachou-Fiocruz, \\ Av. Augusto de Lima 1715, Barro Preto, 31190-002 Belo Horizonte, MG, Brasil
}

Using media discourse analysis for material published by the press on schistomisasis in the city of Jaboticatubas, the possible determining factors of narrative and discursive constructions in the diffusion of information are discussed. It was observed that media discourse treats schistosomiasis in 1962 as something from the natural order. By 1997 and 1998, the media discourse strategies reveal ideological treatment in favor of certain social segments. Situations are identified in which social agents in specific contexts construct the meanings of this endemic disease. It was concluded that the economic organization of space was a determining factor in the production and circulation of the media discourses.

Key words: schistosomiasis - discursive media - journalistic construction

The interaction between health and communication is currently translated into a multidisciplinary field, which can disclose the relations and real possibilities for learning in both areas of knowledge (Minayo 1995). In the same way, Rondelli (1995) argues that the means of communication are the place for enlarging the exchange of discourses constructed in various fields of knowledge, which find in the media their place of divulgation, amplification, and repercussion. The relation between the means of communication and health, as media discourse appropriates the health/disease process, has especially been an object of various discourses (Schall \& Modena 2005).

In health, the spaces in the media for defending interests are formed as networks through which cooperation and the visibility/invisibility conflict pass, and where subjects are situated socially and symbolically. According to Pitta (1995), these networks are built upon profound social inequality and, in the same way, in areas also unequal in the concentration of communication technologies, speed of access to information, speed of decision-making power, internal activities, and silences.

With respect to the health/disease process, individuals are first of all both subjects and objects: subjects, because they are responsible for transforming the process and making it dynamic as a "process", and object, because it is in them that transformations are observed. Individuals, therefore, find in the communications media, in media discourse and given opinions, a broad spectrum of influence on their attitudes and behavior, which can obviously determine important aspects of guidance acquired by a specific disease event (Bevilacqua et al. 2000).

Financial support: Fapemig, CNPq. This article is part of the research of the first author postdoctoral program.

+ Corresponding author: vtschall@ cpqrr.fiocruz.br

Received 25 May 2006

Accepted 26 June 2006
In general, based on the reflections of Thompson (1995), the media can be defined as a complex cultural system that has a symbolic dimension, with a constant play between signs and meanings. The idea of this dialogue includes the (re)construction, storage, production, and circulation of products replete with meanings both for the media that produce them and for those who consume them. The media as a cultural system also includes a contextual dimension, since media products are social phenomena situated in specific contexts.

According to the author, the media in our time has a determinate place in the process of construction and circulation of events, especially owing to their abundance and their influence on everyday social life. They confer visibility on events and information, reducing spatial and temporal barriers, reshaping borders between space and time, and making possible new communication beyond face-to-face interaction.

In the same way, for Schröder (2000) we are inserted in an increasingly symbolic reality. The capital with the predominant value nowadays is symbolic capital. And it is the communications media that creates and legitimates this capital.

With the interactions between health and communications regarded in this way, this study aims at identifying the determinants and representations in the discourse of the print media on schistosomiasis in Jaboticatubas.

\section{METHODOLOGY}

A survey was made of the articles published during the period 1997-1998, in the newspaper Estado de Minas, the main vehicle of the press in the capital of Minas Gerais. The research was carried out using articles preserved on microfilm by the managers of newspaper documentation, from where the material published in 1962 in the magazine $O$ Cruzeiro was also obtained.

The content of the articles and the central idea of the titles were classified according to Thompson's proposal (1995). The first step was identification, starting from the expressions or phrases of the units of meaning. The units of meaning that had semantic similarities were grouped 
into categories. From these discursive expressions, interpretation took place within the model of ideology proposed by Thompson (1995), which distinguished five general modes, with their respective strategies, through which ideology may work, according to the Table.

TABLE

\begin{tabular}{|c|c|}
\hline General modes & $\begin{array}{l}\text { Some typical strategies of symbolic } \\
\text { construction }\end{array}$ \\
\hline Legitimation & $\begin{array}{l}\text { Rationalizing } \\
\text { Universalizing } \\
\text { Narrativizing }\end{array}$ \\
\hline Dissimulation & $\begin{array}{l}\text { Displacement } \\
\text { Euphemism } \\
\text { Tropes (synedoche, metonymy, metaphor) }\end{array}$ \\
\hline Unification & $\begin{array}{l}\text { Standardization } \\
\text { Symbolization of the unit }\end{array}$ \\
\hline Fragmentation & $\begin{array}{l}\text { Differentiation } \\
\text { Expurgation of the other }\end{array}$ \\
\hline Reification & $\begin{array}{l}\text { Naturalizing } \\
\text { Eternalizing } \\
\text { Normalizing/making passive }\end{array}$ \\
\hline
\end{tabular}

The criterion was to select certain symbolic forms that clearly carried ideological meaning, understanding by ideology the production of meaning at the service of power. For Thompson (1995), the news reveals ideological content, that is, it is constituted as symbolic forms whose meanings serve to create or maintain relations of domination.

The attempt was made to identify the representations and strategies inserted in the media discourses and social conditions of their production and circulation.

\section{RESULTS AND DISCUSSION}

The first article that specifically deals with schistosomiasis in Jaboticatubas, in the year 1962, published in the magazine $O$ Cruzeiro, has an eminently informative content. Biological aspects related to the disease are given, such as its parasitic character and form of transmission, as well as explanations about control mechanisms. One of the titles of the article warns about the forms of transmission of the disease: "In the interior of Minas, the disease is brought into the home through the water". The text, with a photograph of a local classroom, reads: "Eighty percent of the children of this city show signs of contamination. The disease is so common there that the population sees it as a natural thing. The children are the greatest victims. The parasites enter the home through the water supply".

The media text is constructed in such a way that it leads the reader to associate schistosomiasis in the city as something of the natural order.

Moving to the decade of 1990, at the beginning of newspaper material on schistosomiasis, the regional coordinator of the National Foundation of Health, Dr João Carlos Pinto Dias was interviewed on February 22, 1997. When he was asked about the endemic disease in that region, he returned the question to the reporter, in this way: "Before you speak, I want to ask you a question. Why all this show now? This has been known for a long time!" By appropriating this question, we intend to show how the press saw schistosomiasis at distinct historical moments.

On discussing the media and the mystification of health technologies, Oliveira (1995) writes that discourses are socially situated and are always the result of a symbolic set of forces that attempt to name, question, place in a hierarchy or activate social subjects. It is for this reason that we cannot consider the discourse (the textual expression of the messages) as a mere transmission of information, but rather as a reality that can only be made explicit in certain conditions by those who have the competence to question distinct social agents. The real aspect of this discourse is ideologically and aesthetically constructed, the role of the media being ideological promoters of social space (Coimbra 2001).

Media discourse strategies - From 1997 on, the media texts have an alarmist and intimidating character, associated with affective and cognitive aspects. Various metaphors are employed. A few titles of articles are here transcribed:

"The Serra Pelada of Tourism": Estado de Minas (Feb 22, 1997), p. 8

"Suicide Tourism": Estado de Minas (Feb 23, 1997), p. 7

“New Year's Eve Accusation": Estado de Minas (Feb 22, 1997), p. 8

"Vitality Ill": Estado de Minas (Feb 23, 1997), p. 7

"Pact of Silence": Estado de Minas (Feb 22, 1997), p. 8 p. 7 .

"End of Feudalism": Estado de Minas (Feb 23, 1997),

"The area needs every one of us, before it dies and we die with it from its sadness and the schistose of our ignorance" (Editorial 1997).

For Alves and Rabelo (1999), imagistic conceptions of metaphor are based on the principle that the function of metaphor is to create an image of a given reality endowed with emotional significance. Thus, metaphor has affective roots and the relation between its terms basically expresses an emotive content: "Metaphors do not simply constitute an isomorphic mapping of one conceptual scheme onto another. They go beyond analogy insofar as they transform the topic by interaction with sensory, affective, cognitive aspects of the juxtaposed elements" (Kirmayer 1993: 172).

A metaphorical statement has a communicative intentionality, and every communicative intention necessarily involves the transmission of a message between a sender and a receiver. "The metaphor necessarily emerges at the core of the interaction, in social situations, and its comprehension is not only a projection of the autonomous and reflective activities of the interlocutors. The comprehension of a metaphorical utterance always takes place in the terms of what is given in the situation of the commu- 
nicative exchange. The subject comprehends through a world that partakes of signifieds, in such a way that the metaphor reverts to the world of intersubjectivity" (Alves \& Rabelo 1999).

In the newspaper history of schistosomiasis in Jaboticatubas, the metaphor "schistose in the Cipó region is the tip of the iceberg": [Estado de Minas (Feb 22, 2, 1997), p. 8], constructs an image of something not immediately visible. In this way, the metaphor serves as a signal that other unrevealed determining factors and other possibilities of exposing the issue exist. It offers possibilities and directions for understanding the theme.

Ricoeur (1987) says that "metaphors constitute the resolution of an enigma, since they point in the direction of a future, in which the action shown is finally directed toward a conclusion that can be anticipated". Thus, we find it appropriate to return to the question of Dr Dias: Why all this show now? This has been known for a long time!

The organization of space and diseases - We believe that what goes beyond the tip of the iceberg that determines the media discourse has to do with the modification of the organization of space in the area. The impact of schistosomiasis on tourism and the hotel industry was fundamental in the publication of information, as observed in the following transcriptions:

"Will they (the businessmen of the area) hurry up and make up their minds? The tourists need to be warned!": Estado de Minas (Feb 22, 1997), p. 8.

"The mayor of Santana do Riacho believes that it will be possible to gradually recover number of customers of the hotels, inns and restaurants, which has decreased by as much as 70\% since the beginning of 1997": Estado de Minas (April 18, 1998), p. 28.

"The hotel owners have also begun to take heart": Estado de Minas (April 18, 1998), p. 28.

"Jaboticatubas, as an ideal area for tourism has the obligation of drawing up this directive plan from an environmental viewpoint": Estado de Minas (April 18, 1998), p. 28.

"In the opinion of an olderwoman of Jaboticatubas, many people are worried about the area because they like the place. Others only have an economic advantage. But at this time all the arguments and concerns are also valid": Estado de Minas (Feb 22, 1997), p. 9.

Studies made by several authors, such as Pessoa (1978), Barreto (1982), Silva (1986, 1988, 1997), and Barata (2000) suggest that the occurrence, distribution, and maintenance of certain illnesses are associated with the modifications made by man on the natural ecosystems by altering them from their natural to a historical condition and consequently transforming them, according to Coura-Filho (1997), into artificial ecosystems, that is, altered or constructed by human manipulation. This modification/organization results in a complex network of causation/consequence. In the health/disease process, human action on an environment generates a system of relations characterized by this transformed space, which may or may not be proper for the setting of certain diseases.

In modern society, the production and organization of space takes place through the process of labor, which as a social agent leads to territorial transformations for the construction of differentiated spaces according to the interests of production at the time. Therefore, the greatest determining factor of the organization of space is the economic one, which reorganizes space in accordance with the needs of the activities to be developed.

The first theoretical study of the concept of space applied to epidemiology was made by Pavlovsky, the Russian parasitologist, who in the 1930s developed the theory of natural foci of transmittable diseases. The modification of space or the landscape would determine ecological changes in the pathobiocenosis, altering the circulation of the infectious agent. Even though Pavlovsky's theory of natural foci is too restricted for the current needs of epidemiology, the model of the natural foci and their transformation by human action with the resulting alteration of the epidemiology of a disease is fundamental for the analysis of space as a category. Space, in its classical conception in epidemiology, is only the substrate that has an influence through natural phenomena like climate. According to this conception, space is static, immutable, a spectator rather than a participant (Silva 2000).

The greatest determining factor in the organization of space is economic need, which will reorganize it according to the needs of the activities that require development, whether agriculture, mining, the transportation of merchandise, energy production, the manufacture of products, or the building of cities. Whatever this activity is, it will determine to a greater or lesser degree the organization of space. The same thing is seen with urban space, which is successively organized and reorganized. The work of Santos (1978) demonstrates the process of organizing urban space in the Third World according to the needs of the economy.

Massara (2005) shows that in Jaboticatubas the modification of the environment was considerable in the last decade. Rural tourism, an important source of income, has transformed once productive old farms and the areas of country houses into inns, resorts and luxury condos. In this new scenario, the intensive use of waterways coincides with trails and roads where the population circulates.

Investment in tourism in the region has been intensively consolidated, as can be seen in the report published in the "Amuse Yourself" section of the Estado de Minas, February, 2006: "The object of study for scientists, naturalists, and educators interested in the wealth of the biodiversity of the locale, Serra do Cipó has also been turning into an object of desire for tourists".

Operational strategies of ideology - As for media discourse strategies, using the theoretical and methodological procedures of Thompson (1995), we can clearly identify the use of fragmentation as a mode of ideological operation through two of its strategies: the first is differentiation, which is defined by Thompson (1995, p. 87) as "the emphasis on distinctions, differences and divisions among persons and groups, supporting the characteris- 
tics that make them different and prevent them from becoming an effective challenge to existing relations". Differentiation, in this study, occurs when the resident population of the endemic disease area, who would represent a risk to those people who frequent or reside in the uncontaminated area. This strategy is clearly perceived in nearly all the published newspaper reports.

The second strategy employed in the media text is that of expurgating the other, defined as being "the construction of an enemy, internal or external, who is portrayed as evil, dangerous or threatening and against whom individuals are called upon to collectively resist or expel" (Thompson 1995, p. 87). The differentiated treatment conferred by the press reinforces the social inequalities to which the residents of the contaminated area are submitted. The indication of the existence of the disease among this population appears as follows:

"Schistosomiasis is active in the region among local people. We do not examine tourists": Caderno Ecológico (Mar 24, 1997), p. 16.

"Some locales and municipalities, like Jaboticatubas, and even in Caminho da Serra show evidence of transmission and infected people, as well as snails, the intermediary agent. This has been known for a long time": Estado de Minas (Abr 18, 1998), p. 28.

According to Castro (1997), the characteristic mode of the "character" created by the media occurs through the mechanism of seduction, that is, the persona is a seducer who seeks to fascinate the other with his image. This mechanism will occur insofar as "the seduction is directed toward the one who, from the other side of the scene - the receiver - lets himself be fascinated by the theatricality, one of the operative modes privileged by the media in the composition of the story of the featured character". It is in this dimension of theatricality that the media story "hooks" the receiver and produces the seduction that enthralls him.

The media, therefore, in dramatizing the character's story with the aim of seducing the receiver, creates a space in which the social is presented in a theatrical form, making public the contours of social reality that are mobilized in this dramatization. In this way, the receiver, here converted into spectator, imaginatively experiences the contours of the social that are mobilized in the actions of the media character. The theatricalization of the social as an operative mode of the media character exercises its power of seduction in a non-violent and non-authoritarian way, for the dramatization of the social is a kind of dissimulation that aims at distracting attention from elements that cause repulsion or refusal and at constructing something attractive to move the object of seduction in the direction intended by the seducer (Castro 1997).

Anchoring in constructing the story of the endemic disease - Another media discourse strategy used was anchoring. According to Moscovici (2004), the function of social representation is to make familiar that which is unknown to us, since it is a specifically human difficulty to deal with the unfamiliar. One of the most common forms of creating social representations is the process called an- choring, a way of associating the unknown with some category already familiar to the subject. In the anchoring practiced by the media, the representation of schistosomiasis is associated with ecology. In the ecological dimension, the anchored categories are polluted rivers, dirt, filth, and pollution. What attracts attention on a first reading is the associative nexus between the two events. The text is full of loaded terms, as can be seen here:

"It's time to have environmental consciousness and not let that paradise sink into urine, feces, schistose, and misery, ending in a slow, agonizing death": Estado de Minas (Feb 22, 1997, p. 8).

"Although the neighboring region is endemic there was no contamination of the water in the areas most visited by tourists. This stretch is between the cities of Santana do Riacho and Jaboticatubas (70 km from Belo Horizonte) at the limits of the Soberbo, Gaviões, Mascates and Cipó rivers, where the hotels, inns, and restaurants are concentrated": Estado de Minas (April 18, 1998, p. 28).

Scientific discourse as a discursive strategy - We must emphasize that one of the thematic axes used by the press is characterized by scientific discourse. Privileging scientific discourse confers verisimilitude and credibility on the material, as seen in similar studies that analyze narrative constructions and discourses on cloning (Costa \& Diniz 2000). Media discourse uses science, since the medical and scientific conceptions of health/disease have an important cultural role in our society, to give value to the information of which they are the vehicle. It is not a question of the truth of the divulged knowledge but to understand that at the same time the press appropriates this discourse as a way of attributing "a truth" to its material, the knowledge become public acquires legitimacy in society, according to Camargo Junior (1986):

...the great axis of sustaining the production of meaning in our society is called "science." Even with a more vehement critique now than thirty or forty years ago, the hegemonic role of science in our culture is not much shaken...it is enough to say that, in the west, to say that something is scientific is equivalent to saying that it is true, well-founded, deserving of belief. A fundamental role in this process of ordering the world is played by the means of mass communication. Showing almost invariably a magical view of science, where argument is substituted by the appeal to the authority of scientists, scientific divulgation is an important arena for the establishment and diffusion of truths.

The social effect of the media has been focused on the perspective of "agenda setting," a hypothesis according to which the media, through the placement and occurrence of the news, has determined the topics that the public will discuss. According to this hypothesis, by imposing the themes to be discussed by the public, it established priorities, hierarchizes events, legitimates and orders the topics of discussion.

This phenomenon was especially illuminating in the case of Jaboticatubas. After the publication of the material, society began to react. Representatives of local poli- 
tics (mayor, alderman), the scientific community (ICBUFMG, CPqRR-Fiocruz), hotel owners, the resident population in the area, and tourists expressed themselves.

Rubim (2000) says that the empirical demonstration of agenda setting is quite simple: "It suffices to listen to the morning conversations in the bars, work places, bakeries, waiting-rooms, schools". For the author, to set an agenda is to choose the right moment and the right place to diffuse information. It is to establish not only what is going to be discussed but how and by whom.

Considerations - The interpretive reading of a communications fact shows that information carries meanings that can mystify a reality that is always contradictory and multifaceted. In an epistemological perspective, which does not allow the supposed neutrality both of science and human action and which does not foresee that the symbolic forms are produced in a context that is never neutral, never disconnected from human interests and emotions, we can understand better the present meanings in these contradictions.

The subject of schistosomiasis in the Serra do Cipó and Jaboticatubas should give the reader, in a critical and educational way, the knowledge and the revelation of a reality. What was revealed through interpretive analysis is the existence of an ideological treatment positioned in favor of certain social segments, that is, segments linked to the tourist enterprise and the occasional visitors of the region, insofar as it does not in the same proportion clarify the arguments related to maintaining the endemic disease in "non-tourist" areas.

It is our objective to establish the impact and repercussions of this news material on the residents of Jaboticatubas, for we could not leave aside an essential part of the process, which is the study of the reception and appropriation of the messages coherent with the methodological development suggested by Thompson (1995). To conclude, we should make it clear that the interpretations given here are subject to new interpretations and resignifications.

\section{REFERENCES}

Alves PCB, Rabelo MCM 1999. Significação e metáforas na experiência da enfermidade. In Experiência de Doença e Narrativa, Fiocruz, Rio de Janeiro, p. 171-186.

Barata RB 2000. Epidemiologia e ciências sociais. In RB Barata, R Briceño-León (eds), Doenças Endêmicas: Abordagens Sociais, Culturais e Comportamentais, Fiocruz, Rio de Janeiro, p. 313-330.

Barreto ML 1982. Esquistossomose Mansônica: Distribuição da Doença e Organização Social do Espaço, Universidade Federal da Bahia, Salvador, 102 pp.

Bevilacqua PD, Paixão HH, Castro MCPS, Modena CM 2000. Leishmaniose visceral: história jornalística de uma epidemia em Belo Horizonte, Brasil. Interface - Comunicação, Saúde, Educação 4: 83-102.

Caderno Ecológico 1997. Estado de Minas, Belo Horizonte, p. 16.

Camargo Júnior KR 1986. Medicina, medicilização e produção simbólica. In AMR Pitta, Saúde \& Comunicação: Visibi- lidades e Silêncios, Hucitec-Abrasco, São Paulo, Rio de Janeiro, p. 29-55.

Castro MCPS 1997. Na Tessitura da Cena, a Vida: Comunicação, Sociabilidade e Política, UFMG, Belo Horizonte, 308 pp.

Coimbra CMB 2001. Mídia e produção de modos de existência. Psicologia: Teoria e Pesquisa 17: 1-4.

Costa SIF, Diniz D 2000. Mídia, clonagem e bioética. Cad Saúde Públ 16: 155-162.

Coura-Filho P 1997. Distribuição da esquistossomose no espaço urbano. 2. Aproximação teórica sobre a acumulação, concentração, centralização do capital e a produção de doenças. Cad Saúde Públ 13: 415-424.

Enfrentando a Verdade 1997. Estado de Minas, Belo Horizonte, p. 8.

Fim do Feudalismo 1997. Estado de Minas, Belo Horizonte, p. 7.

Kirmayer LJ 1993. Healing and the invention of metaphor: the effectiveness of symbols revisited. Culture, Medicine and Psychiatry 17: 161-195.

Laudo Comprova Qualidade das Cachoeiras do Cipó 1998. Estado de Minas, Belo Horizonte, p. 28.

Massara CL 2005. Investigação e Análise de Estratégias para o Controle da Esquistossomose: um Estudo em Área Endêmica de Minas Gerais, Brasil, Fiocruz, Rio de Janeiro, 114 pp.

Minayo MCS 1995. Prefácio. In AMR Pitta, Saúde \& Comunicação: Visibilidades e Silêncios. Hucitec-Abrasco, São Paulo, Rio de Janeiro, p. 3-6.

Moscovici S 2004. Representações Sociais: Investigação em Psicologia Social. Vozes, Petrópolis, 404 pp.

Oliveira VC 1995. Os mídias e a mitificação das tecnologias em saúde. In Pitta AMR, Saúde \& Comunicação: Visibilidades e Silêncios, Hucitec-Abrasco, São Paulo, Rio de Janeiro, p. 25-37.

Pacto do Silêncio 1997. Estado de Minas, Belo Horizonte, p. 8.

Pessoa S 1978. Ensaios Médico-sociais, Cebes-Hucitec, São Paulo, $380 \mathrm{pp}$.

Pitta AMR 1995. Interrogando os campos da saúde e da comunicação: notas para o debate. In AMR Pitta, Saúde \& Comunicação: Visibilidades e Silêncios, Hucitec-Abrasco, São Paulo, Rio de Janeiro, p. 239-266.

Ricoeur P 1987. Teoria da Interpretação, Edições 70, Lisboa, $109 \mathrm{pp}$.

Rondelli E 1995. Mídia e saúde: os discursos se entrelaçam. In AMR Pitta, Saúde \& Comunicação: Visibilidades e Silêncios, Hucitec-Abrasco, São Paulo, Rio de Janeiro, p. 38-47.

Rubim AAC 2000. A contemporaneidade como idade mídia. Interface - Comunicação Saúde Educação 7: 25-36.

Santos M 1978. Os dois circuitos da economia urbana dos países subdesenvolvidos. In M Santos, O Espaço Dividido, Livraria Francisco Alves, Rio de Janeiro, p. 21-64.

Schall VT, Modena CM 2005. As novas tecnologias de informação e comunicação em educação em saúde. In MCS 
Minayo, CEA Coimbra Jr (eds), Críticas e Atuantes: Ciências Sociais e Humanas em Saúde na América Latina, Fiocruz, Rio de Janeiro, p. 245-255.

Schröder C 2000. Apresentação. In PA Guareschi, Os Construtores da Informação: Meios de Comunicação, Ideologia e Ética, Vozes, Petrópolis, p. 9-10.

Serra Pelada do Turismo 1997. Estado de Minas, Belo Horizonte, p. 8.

Silva LJ 1986. Desbravamento, agricultura e doença de Chagas no Estado de São Paulo. Cad Saúde Públ 2: 124-140.

Silva LJ 1988. Organização do espaço e doença. In Textos de Epidemiologia, Cebes-Hucitec, São Paulo.
Silva LJ 1997. O conceito de espaço na epidemiologia das doenças infecciosas. Cad Saúde Públ 13: 585-593.

Silva LJ 2000. A ocupação do espaço e a ocorrência de endemias. In RB Barata, R Biceño-León (eds), Doenças Endêmicas: Abordagens Sociais, Culturais e Comportamentais, Fiocruz, Rio de Janeiro, p. 139-150.

Thompson JB 1995. Ideologia e Cultura Moderna, Vozes, Petrópolis, $427 \mathrm{pp}$.

Turismo Suicida 1997. Estado de Minas, Belo Horizonte, p. 7. Vitalidade Doente 1997. Estado de Minas, Belo Horizonte, p. 7.

Xistose no Cipó (fim): apenas a ponta do iceberg 1997. Estado de Minas, Belo Horizonte, p. 11. 